\title{
Successful Prophylaxis Against Experimental Streptococcal Endocarditis with Bacteriostatic Antibiotics
}

\author{
M. P. Glauser and P. Francioli
} From the Division des Maladies Infectieuses, Département de
Médecine, Centre Hospitalier Universitaire Vaudois, Lausanne, Switzerland

\begin{abstract}
Because bacteriostatic concentrations of vancomycin are effective in prophylaxis against endocarditis due to Streptococcus sanguis in rats, the efficacy of three other bacteriostatic antibiotics was investigated against three different streptococcal species that cause subacute endocarditis in humans: Streptococcus intermedius, $S$. sanguis, and Streptococcus mitior. Rats were challenged by intravenous injection of $2 \times 10^{5}$ colonyforming units of streptococci $24 \mathrm{hr}$ after intracardiac insertion of a transaortic catheter and $30 \mathrm{~min}$ after intravenous injection of various doses of clindamycin, erythromycin, and doxycycline. Significant protection was achieved with all three antibiotics, but only clindamycin was fully effective against all three species at doses that simulated serum levels achievable in humans after oral administration. Endocarditis was prevented by antibiotic concentrations in serum far below minimal bactericidal concentrations for these streptococci. Furthermore, serum at the time of bacterial challenge was not bactericidal. Therefore, single doses of nonbactericidal antibiotics prevented endocarditis in rats by mechanisms other than bacterial killing.
\end{abstract}

Recommendations for antibiotic prophylaxis against bacterial endocarditis require the administration of multiple high doses of bactericidal antibiotics and parenteral administration for high-risk patients [1]. These recommendations are based largely on studies in rabbits and have presented a number of practical problems. Prolonged or parenteral administration of prophylactic antibiotics is far more expensive and less acceptable to both patients and their dentists than a single oral dose. Poor compliance may jeopardize the effectiveness of regimens involving multiple or parenteral doses [2]. There are also important limitations in the experimental data on which the recommendations for prophylaxis during dental procedures are based. The experimental studies involved only rabbits and a single strain of Streptococcus sanguis [3, 4]. Moreover, failure of certain antibiotic regimens in

Received for publication March 9, 1982, and in revised form June 30, 1982.

This work was presented in part at the 21 st Interscience Conference on Antimicrobial Agents and Chemotherapy, held in Chicago in November 1981, and at the Second International Symposium on Infections in the Immunocompromised Host, held in Stirling, Scotland, in June 1982.

We thank Dr. J. A. McCutchan for criticism and comments and $\mathbf{J}$. Kaelin for technical assistance.

Please address requests for reprints to Dr. M. P. Glauser, Division des Maladies Infectieuses, Département de Médecine, Centre Hospitalier Universitaire Vaudois, 1011 Lausanne, Switzerland. the rabbit model could be due to the number of microorganisms used to induce infection, which greatly exceeded that found in humans after dental manipulation [2]. These problems as well as possible failures with the presently recommended regimens in humans [5] have prompted us to continue experimental studies of the prevention of bacterial endocarditis.

Recent experiments with vancomycin in rats [6] and rabbits [7] introduced the possibility of mechanisms other than bacterial killing operating in the prevention of endocarditis. Therefore, the present study was undertaken to test three nonbactericidal antibiotics (erythromycin, clindamycin, and doxycycline), against three species of viridans streptococci that are responsible for infective endocarditis.

\section{Materials and Methods}

Microorganisms. Two previously described species of $\alpha$-hemolytic streptococci were used, Streptococcus intermedius (described elsewhere as $S$. sanguis [6]) and $S$. sanguis biotype II (provłded by Dr. D. T. Durack, Duke University Medical Center, Durham, N.C. [3, 4]), as well as a strain of Streptococcus mitior that was also isolated from a patient with bacterial endocarditis. MICs and MBCs of clindamycin (Upjohn Co., Kalamazoo, Mich.), erythromycin (Eli Lilly and Co., In- 
dianapolis), and doxycycline (Pfizer, Zurich) were determined by broth dilution tests, using MuellerHinton broth (Difco Laboratories, Detroit) and 5 $\times 10^{5}$ microorganisms as the inoculum. Special care was taken to avoid the carry-over of antibiotics [8]. The MBC was defined as the lowest concentration of antibiotic that produced $99.9 \%$ killing after $24 \mathrm{hr}$ of incubation.

Antibiotic serum levels and serum bactericidal activity. Serum levels of antibiotics were determined in five rats at each time point by the agar diffusion technique [9]. The serum bactericidal activity of antibiotics against the three streptococci was determined by standard methods [10] $30 \mathrm{~min}$ after iv injection of $50 \mathrm{mg}$ of clindamycin or erythromycin $/ \mathrm{kg}$ of body weight or $10 \mathrm{mg}$ of doxycycline $/ \mathrm{kg}$. The serum bactericidal activity was defined as the highest serum dilution that provided 99.9\% killing after $24 \mathrm{hr}$ of incubation.

Production and prophylaxis of endocarditis. Sterile vegetations were produced in female Wistar rats (weight, 180-200 g) by a modification of a previously described method [6]. In brief, a polyethylene catheter (model no. PP 10; Portex, Hythe, Kent, England) was passed through the aortic valve via the right carotid artery and secured with a silk ligature. Twenty-four hours after catheterization, rats were injected in the tail vein with 0.5 $\mathrm{ml}$ of various concentrations of antibiotics or $0.85 \% \mathrm{NaCl}$. Thirty minutes later $0.5 \mathrm{ml}$ of saline containing $10^{5} \mathrm{cfu}$ of bacteria, the minimal inoculum needed to produce endocarditis in $>80 \%$ of control rats, was injected iv. Rats were killed 48-72 hr after bacterial challenge, and aortic vegetations were excised, weighed, homogenized in $1 \mathrm{ml}$ of $0.85 \% \mathrm{NaCl}$, serially diluted, and plated. Colony counts were done after $48 \mathrm{hr}$ of incubation at $37 \mathrm{C}$. This method permitted the detection of $5 \times 10^{2} \mathrm{cfu} / \mathrm{g}$ of vegetation.

Statistical analysis. The $\chi^{2}$ test with Yates's correction and Student's $t$-test (unpaired) were used for statistical comparisons.

\section{Results}

Antibiotic sensitivity, antibiotic serum levels, and serum bactericidal activity. All three streptococcal species had very low MICs for the three antibiotics tested (figure 1), but MBCs were largely above achievable serum levels (figure 2). At the time of bacterial challenge, serum bactericidal activity against all three streptococcal species was undetectable with any of the three antibiotics.

Prophylaxis of endocarditis with clindamycin. Despite the lack of bacterial killing in vitro, clindamycin at doses of 50 and $20 \mathrm{mg} / \mathrm{kg}$ achieved very efficient prophylaxis against the three streptococci tested (figure 1). The $20 \mathrm{mg} / \mathrm{kg}$ dose produced peak serum levels below the $4.5 \mu \mathrm{g} / \mathrm{ml}$ achieved in humans after an oral dose of $450 \mathrm{mg}$

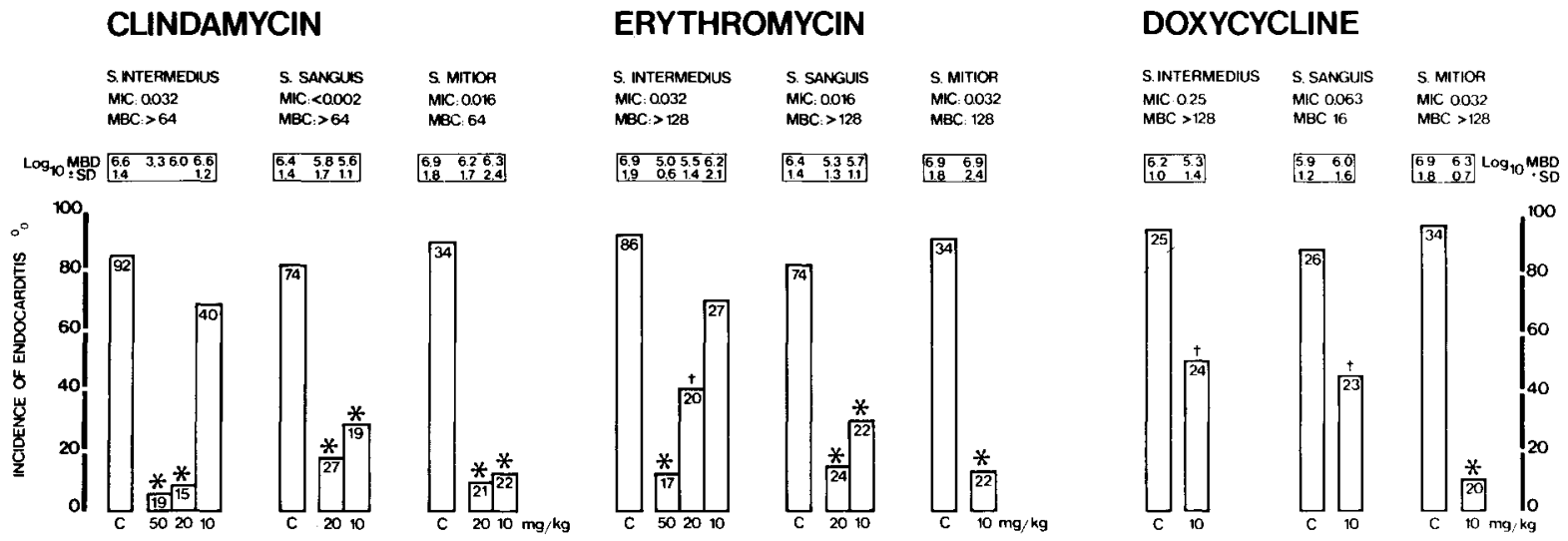

Figure 1. Incidence of endocarditis due to Streptococcus intermedius, Streptococcus sanguis, and Streptococcus mitior after prophylaxis with various doses of clindamycin, erythromycin, and doxycycline administered iv 30 min before bacterial challenge. Numbers within the bars indicate the total number of rats in the groups; numbers beneath the bars indicate the doses $(\mathrm{mg} / \mathrm{kg}$ of body weight) of the prophylactic antibiotics. Results for control rats (C) that were injected iv with $0.85 \% \mathrm{NaCl}$ are shown. Above the bars the log of the mean ( \pm SD) bacterial density (MBD) recovered from infected vegetation in each group are shown in boxes. The MICs and MBCs for the antibiotics are also indicated. Statistical comparisons are as follows: $\left({ }^{*}\right)$ indicates $P<0.01$ in comparison with controls; $(\dagger)$ indicates $P<0.05$ in comparison with controls. 
CLINDAMYCIN

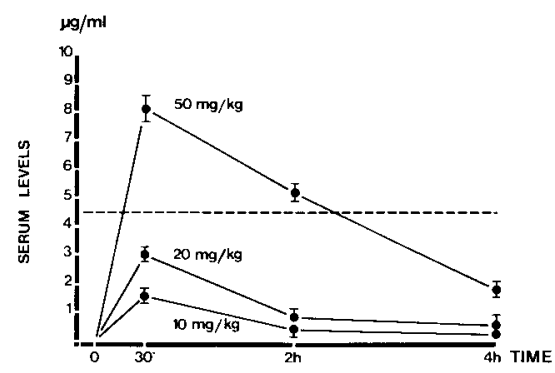

ERYTHROMYCIN

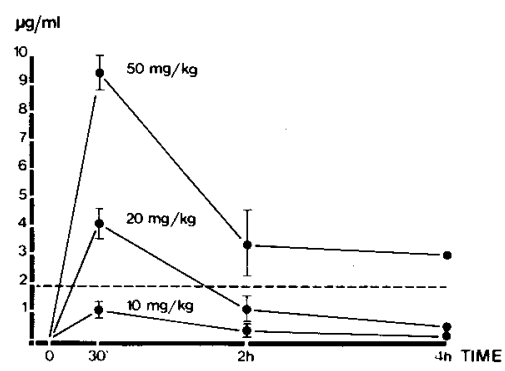

\section{DOXYCYCLINE}

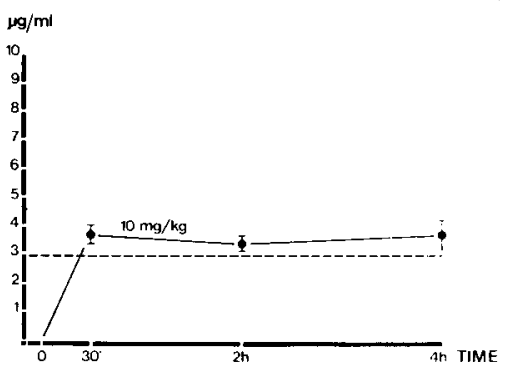

Figure 2. Serum levels of clindamycin, erythromycin, and doxycycline $0.5,2$, and $4 \mathrm{hr}$ after single iv injections in rats. Dotted lines represent peak levels achieved in humans after oral doses of $450 \mathrm{mg}$ of clindamycin, $500 \mathrm{mg}$ of erythromycin, and $200 \mathrm{mg}$ of doxycycline [11].

[11] (figure 2). The $10 \mathrm{mg} / \mathrm{kg}$ dose was not uniformly effective.

Prophylaxis of endocarditis with erythromycin. Although the MICs and MBCs of erythromycin for the three streptococcal species were similar to those of clindamycin, erythromycin was less efficient than clindamycin in preventing endocarditis. With the dose of $10 \mathrm{mg} / \mathrm{kg}$, which produced peak serum levels similar to the $0.5-2.0 \mu \mathrm{g} / \mathrm{ml}$ achieved in humans after an oral dose of $500 \mathrm{mg}$ [11] (figure 2), only endocarditis due to $S$. sanguis and $S$. mitior was significantly prevented. The incidence of infection with $S$. sanguis was $\sim 30 \%$.

Prophylaxis of endocarditis with doxycycline. Although half of that in controls, the incidence of endocarditis due to $S$. intermedius and $S$. sanguis in doxycycline-treated rats was still $>40 \%$ with the dose of $10 \mathrm{mg} / \mathrm{kg}$. This dose produced peak serum levels similar to the $2.8 \mu \mathrm{g} / \mathrm{ml}$ achieved in humans after an oral dose of $200 \mathrm{mg}$ [11] (figure 2).

Quantitative cultures of infected vegetations. For all three streptococcal species, the number of bacteria/g of infected vegetations was similar in control rats to that in rats in which prophylaxis failed (figure 1).

\section{Discussion}

Previous studies in rabbits that had been used to establish current recommendations for the prophylaxis against bacterial endocarditis [1] suggested that bacterial killing is the mechanism responsible for successful protection. This conclusion was based on two observations. (I) There seemed to be a correlation between the efficacy of antibiotics or combinations of synergistic antibiotics in killing bacteria in vitro and the protection obtained in vivo [3]. (2) Bacteriostatic antibiotics such as tetracycline failed to protect from infection [12]. These results served as a basis for the current American Heart Association recommendations of high doses and prolonged administration of bactericidal antibiotics for prophylaxis of endocarditis in humans [1]. However, these experiments in rabbits involved extremely large bacterial inocula. Recent experiments from two different laboratories using inocula that are 2 to $3 \log$ smaller and a single dose of vancomycin as the prophylactic antibiotic have shown that experimental endocarditis can be prevented in the absence of bacterial killing $[6,7]$. Even this smaller inoculum provides a stringent test of antibiotic prophylaxis because the resulting bacteremia is far greater than that observed in humans after oral procedures [2] and produces $80 \%-100 \%$ endocarditis in animals. The rats [6], like high-risk human patients, have a permanent intracardiac foreign body. Therefore, it was of interest to use this model to reexamine the efficacy of single doses of orally absorbable, nonbactericidal antibiotics.

Previous attempts to protect rabbits with clindamycin at doses of $10 \mathrm{mg} / \mathrm{kg}$ against high inocula $\left(10^{8} \mathrm{cfu}\right)$ of $S$. sanguis failed [4]. In the present study, we found that this same dose produced similar peak concentrations in rats and often failed to protect against smaller inocula $\left(10^{5} \mathrm{cfu}\right)$ of three streptococcal species. In contrast, excellent protection was afforded by doubling the dose (20 $\mathrm{mg} / \mathrm{kg}$ ). This protection was achieved by clindamycin levels below those which follow a single 450-mg oral dose in humans. Thus, peak serum levels conveniently achievable in patients pro- 
tected rats from three streptococcal species which colonize the mouth and cause endocarditis in humans. Furthermore, rats were protected at clindamycin levels below the MBCs for these streptococci and in the absence of serum bactericidal activity.

Erythromycin protected rats from endocarditis due to $S$. sanguis and $S$. mitior at doses resulting in serum levels achievable in humans after an oral dose of $500 \mathrm{mg}$. Against both $S$. intermedius in the present experiments and $S$. sanguis in rabbits [4], erythromycin was protective only at doses that resulted in serum levels far above those obtained in humans after oral administration of $500 \mathrm{mg}$ of the drug [11]. Like tetracycline hydrochloride in rabbits [12], doxycycline failed to provide sufficient protection in rats against infection with two of the three species tested. Thus, both erythromycin and doxycycline protected rats against only some streptococcal species at doses usually given orally to patients. As with clindamycin, protection was achieved in the absence of serum bactericidal activity.

Since sublethal concentrations of vancomycin in previous studies $[6,7]$ and three bacteriostatic antibiotics in the present experiments provide protection against endocarditis, mechanisms other than killing must be involved. We investigated in two ways the possibility that bacteriostatic antibiotics might have merely delayed the growth of bacteria in vegetations. (I) We compared the numbers of streptococci in vegetations from infected controls and from animals infected in spite of prophylaxis. If antibiotics suppressed rather than prevented infection, rats in which prophylaxis failed should have fewer organisms in their vegetations than untreated control animals. In fact, we found the same high numbers in both groups of rats (figure 1). (2) We examined animals one week rather than three days after challenge (data not shown) and found no increase in the percentage of animals in which prophylaxis failed. We conclude that bacteriostatic antibiotics prevented, not just suppressed, infection - that is, prophylaxis was an allor-none phenomenon.

Another possible mechanism is suggested from previous experiments with vancomycin. In both rats and rabbits, vancomycin appears to protect by inhibiting adherence of streptococci to sterile vegetations [6, 7]. This interpretation is supported by demonstration in vitro that nonbactericidal concentrations of vancomycin and penicillin prevent adherence of streptococci to platelet-fibrin clots [7, 13]. MICs of clindamycin have similar negative effects on the adherence of Escherichia coli [14] and alter surface structures of streptococci that mediate adherence $[15,16]$. These observations raise the possibility that one mechanism by which clindamycin or other bacteriostatic antibiotics prevented endocarditis is interference with adherence.

Regardless of the mechanism responsible for protection, the present experiments suggest that the use of stringent antibiotic regimens aimed at killing bacteria might not be required for adequate prevention of bacterial endocarditis in humans.

\section{References}

1. Kaplan, E. L., Anthony, B. F., Bisno, A., Durack, D., Houser, H., Maillard, H. D., Sanford, J., Shulman, S. T., Stillerman, M., Taranta, A., Wenger, N. Prevention of bacterial endocarditis. Circulation 56:139A143A, 1977.

2. Petersdorf, R. G. Antimicrobial prophylaxis of bacterial endocarditis: prudent caution or bacterial overkill? Am. J. Med. 65:220-223, 1978.

3. Durack, D. T., Petersdorf, R. G. Chemotherapy of experimental streptococcal endocarditis. I. Comparison of commonly recommended prophylactic regimens. J. Clin. Invest. 52:592-598, 1973.

4. Pelletier, L. L., Jr., Durack, D. T., Petersdorf, R. G. Chemotherapy of experimental streptococcal endocarditis. IV. Further observations on prophylaxis. J. Clin. Invest. 56:319-330, 1975.

5. Durack, D. T., Kaplan, E. L., Bisno, A. L. Twenty-five cases of apparent endocarditis prophylaxis failure: results of a national survey [abstract]. Clinical Research 29:384A, 1981.

6. Bernard, J.-P., Francioli, P., Glauser, M. P. Vancomycin prophylaxis of experimental Streptococcus sanguis: inhibition of bacterial adherence rather than bacterial killing. J. Clin. Invest. 68:1113-1116, 1981.

7. Scheld, W. M., Zak, O., Vosbeck, K., Sande, M. A. Bacterial adhesion in the pathogenesis of infective endocarditis: effect of subinhibitory antibiotic concentrations on streptococcal adhesion in vitro and the development of endocarditis in rabbits. J. Clin. Invest. 68:1381-1384, 1981.

8. Pearson, R. D., Steigbigel, R. T., Davis, H. T., Chapman, S. W. Method for reliable determination of minimal lethal antibiotic concentrations. Antimicrob. Agents Chemother. 18:699-708, 1980.

9. Sabath, L. D., Anhalt, J. P. Assay of antimicrobics. In E. H. Lennette, A. Balows, W. J. Hausler, Jr., and J. P. Truant [ed.]. Manual of clinical microbiology. 3rd ed. American Society for Microbiology, Washington, D.C., 1980, p. 485-490. 
10. Anhalt, J. P., Sabath, L. D., Barry, A. L. Special tests: bactericidal activity, activity of antimicrobics in combination, and detection of $\beta$-lactamase production. In E. H. Lennette, A. Balows, W. J. Hausler, Jr., and J. P. Truant [ed.]. Manual of clinical microbiology. 3rd ed. American Society for Microbiology, Washington, D.C., 1980, p. 478-484.

11. Braude, A. 1. Pharmacology principles. W. B. Saunders, Philadelphia, 1976, p. 68.

12. Southwick, F. S., Durack, D. T. Chemotherapy of experimental streptococcal endocarditis. III. Failure of a bacteriostatic agent (tetracycline) in prophylaxis. J. Clin. Pathol. 27:261-264, 1974.

13. Neuhaus, E., Lowy, F., Chang, D., Horne, D., Tomasz, A., Steigbigel, N. Penicillin tolerant $S$. viridans: effect of penicillin on host-bacterial interaction [abstract no. 356].
In Program and Abstracts of the 20th Interscience Conference on Antimicrobial Agents and Chemotherapy. American Society for Microbiology, Washington, D.C., 1980.

14. Vosbeck, K., Handschin, H., Menge, E.-B., Zak, O. Effects of subminimal inhibitory concentrations of antibiotics on adhesiveness of Escherichia coli in vitro. Rev. Infect. Dis. 1:845-851, 1979.

15. Gemmell, C. G., Peterson, P. K., Schmeling, D., Kim, Y., Mathews, J., Wannamaker, L., Quie, P. G. Potentiation of opsonization and phagocytosis of Streptococcus pyogenes following growth in the presence of clindamycin. J. Clin. Invest. 67:1249-1256, 1981.

16. Fox, E. N. M proteins of group A streptococci. Bacteriological Reviews 38:57-86, 1974. 